\title{
CARBOXYPEPTIDASE Y CATALYZED TRANSPEPTIDATIONS AND ENZYMATIC PEPTIDE SYNTHESIS
}

\author{
by \\ KLAUS BREDDAM, FRED WIDMER and JACK T. JOHANSEN \\ Department of Chemistry, Carlsberg Laboratory. \\ Gamle Carlsberg Vej 10, DK-2500 Copenhagen Valby
}

Keywords: Carboxypeptidase $\mathrm{Y}$, transpeptidation, enzymatic peptide synthesis, peptidylamino-acid-amide hydrolase activity

It is shown that carboxypeptidase $Y$, in addition to its known amidase and peptidase activities, also exhibits peptidyl-amino-acid-amide hydrolase activity, i.e., amino acid amides are released from peptide amides. These three activities were investigated as to their usefulness in catalyzing transpeptidation reactions in the presence of suitable nucleophiles. Using peptides and peptide amides as substrates and amino acids or amino acid amides as nucleophiles, it could be shown that transpeptidation products were formed in accordance to each of the above mentioned activities of carboxypeptidase $\mathrm{Y}$. While transpeptidation via the amidase activity results in an elongation of the peptide chain, transpeptidation via peptidase activity results in the exchange of the C-terminal amino acid residue. If the substrate is a peptide amide, transpeptidation via the peptidyl-amino-acid-amide hydrolase activity will result in the formation of a peptide where the $\mathrm{C}$-terminal amino acid amide is replaced by either an amino acid or an amino acid amide.

As conditions have not yet been found where all three activities are well separated from each other, it is not generally possible to direct these transpeptidations towards a single desired product in high yield. However, the data presented in this paper indicate that for peptides of certain unique amino acid sequences the carboxypeptidase $Y$ catalyzed transpeptidations may be applicable in the field of enzymatic peptide synthesis.

\footnotetext{
Abbreviations: $\mathrm{Ac}=$ acetyl: $\mathrm{Bz}=$ benzoyl; $\mathrm{CBZ}=$ carbobenzoxy; $\mathrm{CPD}-\mathrm{Y}=$ carboxypeptidase $\mathrm{Y} ; \mathrm{DMF}=$ dimethylformamide; FA $=3$-(2-Furylacryloyl)-; HPLC $=$ high pressure liquid chromatography; $\mathrm{NaAc}=$ sodium acetate: TEAF = triethylammonium formate; TEAP $=$ triethylammonium phosphate buffer; All other abbreviations of amino acids. amino acid derivatives and peptides are according to the guideline of the IUPACIUB Commission on Biochemical Nomenclature.
} 


\section{INTRODUCTION}

Carboxypeptidase Y (CPD-Y), unlike the pancreatic carboxypeptidases $\mathrm{A}$ and $\mathrm{B}$, exhibits no absolute requirement for a free carboxyl group in its substrates. The enzyme not only hydrolyses peptides but acts on peptide esters and peptide amides as well (8).

At alkaline $\mathrm{pH}$ values $\mathrm{CPD}-\mathrm{Y}$ exhibits some esterase activity but only very low carboxypeptidase activity (8), the latter being optimal at acidic $\mathrm{pH}$ values. This property of the enzyme, in conjunction with the formation of an acylenzyme intermediate during the hydrolytic process (18), has been exploited for synthesis of peptide bonds using peptide esters as substrates and amino acid derivatives as nucleophiles (29).

Since hydrolysis presumably proceeds via an acyl-enzyme intermediate regardless of the esteror amide nature of the substrate, it is warranted to investigate the possibility of CPD-Y catalyzed acyl-type transpeptidation reaction. Such reactions, well documented for endoproteases $(4,13$, 28), would be of great interest in CPD-Y catalyzed peptide synthesis. In the present paper the results of such studies, employing peptide amides and peptides as substrates, are reported. Furthermore, data are presented on a hitherto unrecognized activity of CPD-Y, i.e. a peptidylamino-acid-amide hydrolase activity.

\section{MATERIALS AND METHODS}

\subsection{Materials}

Carboxypeptidase Y from baker's yeast, a commercial preparation of the Carlsberg Breweries, was isolated by a modification of the affinity chromatography procedure of JoHANSEN et al. (12) and obtained as a lyophilized powder (10\% enzyme in sodium citrate). Before use the enzyme was dissolved in water, desalted on Sephadex G-25 fine $(1.5 \times 25 \mathrm{~cm})$ equilibrated and eluted with destilled water. The concentration of the enzyme was determined spectrophotometrically using $\mathrm{E}_{280 \mathrm{~nm}}^{1 \%}=14.8$. This enzyme preparation was free of Protease A activity as checked by the assay of LEE and RIORDAN (16).

Benzoyl-L-alanine methyl ester, L-leucine amide hydrochloride, L-phenylalanine amide, Lvaline amide hydrochloride, $\mathrm{L}$-alanine amide, $\mathrm{L}$ methionine amide hydrochloride, benzoyl-Lalanine, benzoyl-L-phenylalanine, N-CBZ-L-ala- nyl-glycine, N-CBZ-L-alanyl-L-alanine, N-CBZL-alanyl-L-valine, N-CBZ-L-alanyl-L-phenylalanine, Ac-(Ala) $)_{n} \mathrm{OMe}(\mathrm{n}=2-4)$, and Ac(Ala) ${ }_{n} \mathrm{OH}(\mathrm{n}=1-4)$ were purchased from Bachem, Liestal, Switzerland. L-Valine, Lphenylalanine, N-CBZ-glycyl-L-leucine, $\quad \mathrm{N}$ CBZ-L-phenylalanyl-L-alanine were obtained from Sigma Chemical Company, St. Louis, U.S.A. N-CBZ-L-phenylalanyl-L-leucine, NCBZ-phenylalanyl-L-phenylalanine, N-CBZ-Lphenylalanyl-L-serine, L-threonine amide hydrochloride were from Vega-Fox Chemicals, Tucson, U.S.A. FA-Gly-Leu-OH and FA-GlyLeu- $\mathrm{NH}_{2}$ were the generous gift of Dr. B. HolmQuist, Harvard University, Boston, Mass. U.S.A. Analytical grade solvents and reagents were from Merck, Darmstadt, West Germany. Benzoyl-L-phenylalanyl-glycine was synthesized from benzoylchloride and L-phenylalanyl-glycine according to a method described by AuLD and VALLEE (3).

The following $\mathrm{N}$-protected peptide amides were prepared enzymatically according to the method of WIDMER and JoHANSEN (29): Bz-AlaVal- $\mathrm{NH}_{2}$ (M.P. $250^{\circ} \mathrm{C}$ decomp.), Bz-Ala-Ile$\mathrm{NH}_{2}$ (M.P. $\quad 233-234^{\circ} \mathrm{C}$ ), Bz-Ala-Phe- $\mathrm{NH}_{2}$ (M.P. $220^{\circ} \mathrm{C}$ decomp.), Bz-Ala-Leu-NH $\mathrm{N}_{2}$ (M.P. $187-190^{\circ} \mathrm{C}$ ) Ac-Ala-Ala-Ala-Leu-NH $\mathrm{NH}_{2}$ (M.P. $250^{\circ} \mathrm{C}$ ) and Ac-Ala-Ala-Ala-Ile-NH $\mathrm{NH}_{2}$ (M.P. $>$ $250^{\circ} \mathrm{C}$ ). All these peptides precipitated from the reaction mixture and could be isolated by filtration. Bz-Ala-Ala- $\mathrm{NH}_{2}$ (M.P. $207-209^{\circ} \mathrm{C}$ ), Bz-Ala-Thr-NH $\mathrm{NH}_{2}$ (M.P. $255^{\circ} \mathrm{C}$ decomp.) and Ac-Ala-Ala-Ala-Ala-His- $\mathrm{NH}_{2}$ (M.P. $>250^{\circ} \mathrm{C}$ ) were soluble and thus had to be isolated by HPLC. The method is outlined in detail in the following two examples.

Bz-Ala-Thr-NH $2.200 \mathrm{mg} \mathrm{Bz-Ala-OMe} \mathrm{in} 1$ $\mathrm{ml}$ methanol was added to $20 \mathrm{ml} 0.25 \mathrm{M}$ threonine amide in water, $\mathrm{pH} 9.5$. The coupling reaction was started by adding $3.5 \mathrm{mg} C P D-Y$ in aqueous solution. Using a Radiometer $\mathrm{pH}$-stat the $\mathrm{pH}$ was kept constant at 9.5 with $0.5 \mathrm{~m}$ $\mathrm{NaOH}$. After $30 \mathrm{~min}$, when all the ester had been converted, the solution was poured on 100 $\mathrm{ml}$ methanol. After standing for 6 hours at $4^{\circ} \mathrm{C}$ the denatured enzyme had settled and the supernatant was concentrated on a Büchi Rotavapor to approx. $10 \mathrm{ml}$. Bz-Ala-Thr- $\mathrm{NH}_{2}$ was isolated by HPLC (see section 2.2), using the Waters system and a Waters Radial-Pak A LC 
Cartridge. The conditions were as follows: 50 mM-TEAF, $\mathrm{pH} 4,10 \% \mathrm{CH}_{3} \mathrm{CN}$, isocratic elution, flow: $4 \mathrm{ml} \cdot \mathrm{min}^{-1}$. In six runs of $1.5 \mathrm{ml}$ injection, the peak corresponding to the product was collected and lyophilized. A second lyophilization from water gave a white powder. The purity of the compound was confirmed by rechromatography using TEAP buffer and by amino acid analysis.

Ac-Ala-Ala-Ala-Leu-NH $2.287 \mathrm{mg}$ Ac-AlaAla-Ala-OMe $(50 \mathrm{~mm})$ was added to $20 \mathrm{ml}$ of a solution of $642 \mathrm{mg} \mathrm{H}$-Leu- $\mathrm{NH}_{2} \cdot \mathrm{HCl}(200 \mathrm{~mm})$ in water, $\mathrm{pH}$ 9.5. Under stirring the finely dispersed ester slowly dissolved and then $100 \mu \mathrm{l}$ CPD-Y ( $\left.7 \mathrm{mg} \cdot \mathrm{ml}^{-1}\right)$ was added. After about 15 min the product began to precipitate. The reaction was monitored by HPLC recording the UV-absorption at $210 \mathrm{~nm}$. After $45 \mathrm{~min}$ the reaction mixture contained, besides leucine amide, $\quad 80 \% \quad$ Ac-(Ala) $)_{3}-\mathrm{Leu}_{-} \mathrm{NH}_{2} . \quad 10 \%$ Ac-(Ala) ${ }_{3}-\mathrm{OH}, 10 \%$ Ac-(Ala $)_{3}-\mathrm{OMe}$ plus traces of Ac-Ala-OH and Ac-(Ala) ${ }_{2}-\mathrm{OH}$. The suspension was filtered and washed with a little cold 0.2 м-sodium carbonate $\mathrm{pH} 9.2$, followed by cold water. The white residue was dried in vacuo over $\mathrm{P}_{2} \mathrm{O}_{5}$. The yield was $255 \mathrm{mg}(70 \%)$. The purity was confirmed by rechromatography and by amino acid analysis. The Waters HPLCsystem with a $4.5 \times 250 \mathrm{~mm}$ LiChrosorb RP- 18 $(10 \mu \mathrm{m})$ column was used for the separation, monitoring the eluate at $210 \mathrm{~nm}$. The conditions were as follows: Solvent A: 25 mm-TEAPbuffer, solvent B: $50 \% \mathrm{CH}_{3} \mathrm{CN}$ in $\mathrm{H}_{2} \mathrm{O}$. A concave gradient (No 7) from $10 \% \mathrm{~B}$ to $100 \% \mathrm{~B}$ in $18 \mathrm{~min}$ at a flow of $1.5 \mathrm{ml} \cdot \mathrm{min}^{-1}$ was used.

\subsection{HPLC materials and systems}

Acetonitrile and methanol used for HPLC were from Rathburn Chemicals, Walkerburn, Scotland. Glass-distilled water was used throughout. All buffers and solvents were filtered and degassed using $0.45 \mu \mathrm{m} \mathrm{FA}$ and $0.5 \mu \mathrm{m} \mathrm{FH}$ filters from Millipore Corporation, Bedford, Mass., U.S.A. Reverse-phase support materials, LiChrosorb RP-18 and RP-8, $10 \mu \mathrm{m}$ were obtained from Merck, Darmstadt, West Germany. Stainless steel columns of two internal diameters, 4.5 and $8 \mathrm{~mm}$, in $25 \mathrm{~cm}$ lengths were from Microlaboratoriet, Aarhus, Denmark. The columns were packed by the slurry technique using a mixture of isopropanol and methanol (7:3) and a packing apparatus from Magnus Scientific Instrumentation Ltd., Cheshire, England. Waters Radial-Pak A Liquid Chromatography Cartridges together with a Waters Radial Compression Module (RCM-100) were also employed and gave excellent resolution.

Liquid chromatography systems from Waters and Hewlett-Packard (Model 1084) were used. The Waters system consisted of a Model $6000 \mathrm{~A}$ solvent delivery system, a Model 660 solvent programmer, a Model U6K injector, a Model 450 variable UV-detector, a Waters Data Module, and a WISP $710 \mathrm{~A}$ sample processor.

All desired separations were achieved using suitable flow-rates $\left(1-4 \mathrm{ml} \cdot \mathrm{min}^{-1}\right)$, solvent temperatures $\left(20-45^{\circ} \mathrm{C}\right)$ and gradients of one of the following eluant systems: a) $5 \% \mathrm{CH}_{3} \mathrm{OH}$, $10 \% \mathrm{CH}_{3} \mathrm{CN}$ in $10 \mathrm{~mm}-\mathrm{NaAc}$. $\mathrm{pH} 4$. to $90 \%$ $\mathrm{CH}_{3} \mathrm{OH}, 10 \% \mathrm{H}_{2} \mathrm{O}$; b) $10 \% \mathrm{CH}_{3} \mathrm{CN}$ in $50 \mathrm{~mm}-$ TEAF, pH 4.0 , to $80 \% \mathrm{CH}_{3} \mathrm{CN}$ in $50 \mathrm{~mm}$ TEAF, pH 4.0 ; c) 25 mm-TEAP, pH 4.0, to $50 \% \mathrm{CH}_{3} \mathrm{CN}$ in $\mathrm{H}_{2} \mathrm{O}$. The TEAP and TEAF buffers were prepared according to Rivier et al. (25).

\subsection{Transpeptidation reactions}

Analytical scale experiments were routinely performed in a Radiometer $\mathrm{pH}$-stat assembly (Model TTT la) at room temperature as described earlier (29). The total volume was 1.5 $\mathrm{ml}$ and $\mathrm{pH}$ was maintained throughout the reaction by automatic titration with $0.5 \mathrm{M}$ $\mathrm{NaOH}$. During the reaction 100-200 $\mu$ l aliquots were diluted into $1 \mathrm{ml} \mathrm{CH}{ }_{3} \mathrm{CN}$ to quench the reaction. If necessary, a clear homogeneous solution was generated by addition of water or ethanol. The composition of the samples was then determined by HPLC using the equipment and eluants described in section 2.2. Those products not identifiable with parallel runs of relevant standards were collected from the HPLC and the amino acid composition determined after acid hydrolysis. In cases where all compounds of interest had a common dominant chromophore (N-benzoyl-, N-CBZ) the concentration could directly be assessed from the integrated peak areas. When no such dominant chromophore was shared, as in the $\mathrm{N}$-acetyl-(Ala) $)_{n}-X$ series, entire peaks were collected 
and the concentrations determined by quantitative amino acid analysis after acid hydrolysis.

\section{RESULTS}

\section{1. $\mathrm{pH}$ dependence of peptidase and amidase activity}

It was expected that FA-Gly-Leu- $\mathrm{NH}_{2}$ would be a substrate of CPD-Y since the enzyme already had been characterized as an amidase (8). However, the observation that leucine amide was released in addition to ammonia and leucine was a surprise. Measuring the rate of hydrolysis of FA-Gly-Leu- $\mathrm{NH}_{2}$ spectrophotometrically, only the cleavage of the Gly-Leu bond is monitored (6). Thus, the observed activity is the sum of a direct release of leucine amide plus a sequential release of first ammonia and then leucine. The influence of $\mathrm{pH}$ on the cleavage of the Gly-Leu bond in FA-Gly-Leu- $\mathrm{NH}_{2}$ is shown in Figure 1A. At basic $\mathrm{pH}$ values where CPD-Y does not exhibit carboxypeptidase activity towards FA-

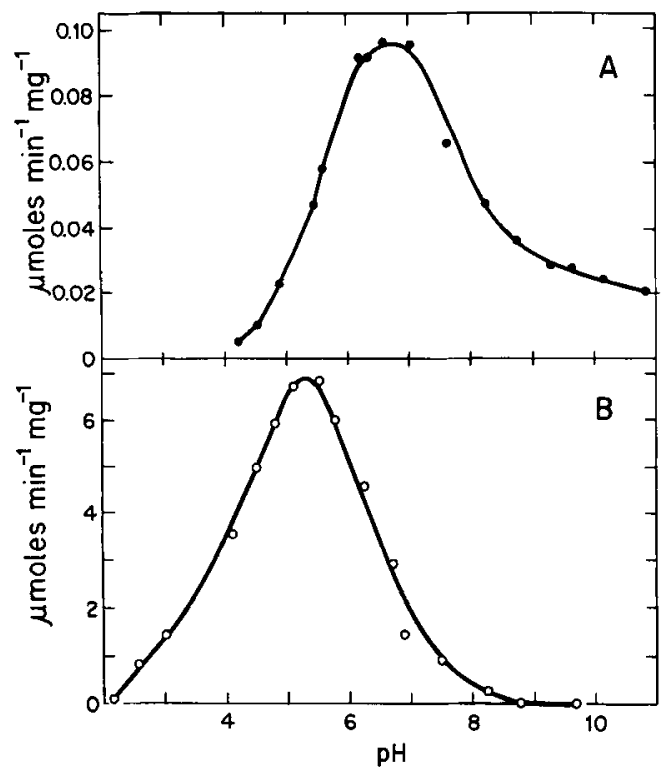

Figure 1. pH-Dependence of the hydrolysis of FAGly-Leu-NH $\mathrm{NH}_{2}$ (A) and FA-Gly-Leu-OH (B) using 0.5 $\mathrm{mm}$ substrate and $50 \mathrm{~mm}$ buffer (glycine/ $\mathrm{HCl}$, sodium acetate, sodium phosphate, Tris, 2-amino-2methyl-1,3-propanediol and sodium carbonate).

The ordinate shows specific activities, measured as the increase in absorbance at $337 \mathrm{~nm}$. CPD.Y = $0.6-11 \mu \mathrm{M}$. Specific activities were calculated as described by FEDER and STUCK (6).

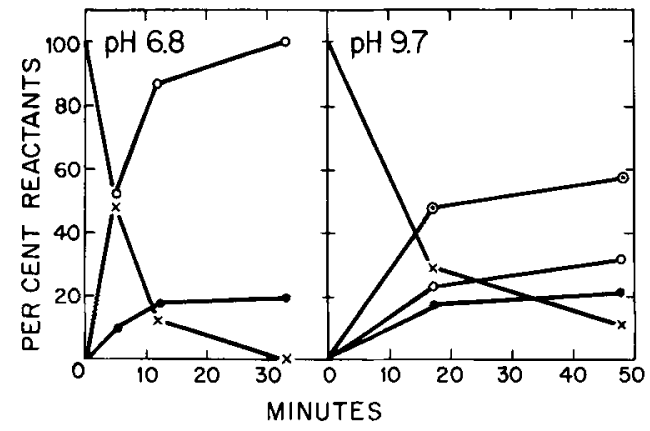

Figure 2. Influence of $\mathrm{pH}$ on the CPD-Y catalyzed hydrolysis of FA-Gly-Leu- $\mathrm{NH}_{2}$.

Conditions used: $0.5 \mathrm{~mm}-\mathrm{FA}-\mathrm{Gly}-\mathrm{Leu}-\mathrm{NH}_{2}, 50$ mm buffer (sodium phosphate, sodium carbonate), 5 mM-EDTA, CPD-Y $=9 \mu \mathrm{M}$. The content of FA-Gly$\mathrm{OH}, \mathrm{FA}-\mathrm{Gly}$-Leu-OH and FA-Gly-Leu-NH 2 in the reaction mixture was determined by HPLC, measuring at $302 \mathrm{~nm}$, the isosbestic point of these compounds. The release of $\mathrm{H}-\mathrm{Leu}-\mathrm{NH}_{2}$ was detected by direct analysis on the amino acid analyzer. $-\mathrm{O}-\mathrm{O}-$ FA-Gly, $-\odot-\odot-$ FA-Gly-Leu, $-x-x-\quad$ FA-Gly-Leu-NH $\mathrm{NH}_{2}, \quad-\mathbf{0}-$ $\mathrm{H}-\mathrm{Leu}-\mathrm{NH}_{2}$. The ordinate indicates relative concentrations.

Gly-Leu-OH (Figure 1B) the observed spectrophotometric change, using FA-Gly-Leu- $\mathrm{NH}_{2}$ as substrate, suggest a direct release of leucine amide. This activity will be referred to as peptidyl-amino-acid-amide hydrolase activity, and was documented by identification of the products of the reactions carried out at $\mathrm{pH} 6.8$ and $\mathrm{pH} 9.75$ by HPLC (Figure 2). At both $\mathrm{pH}$ values leucine amide is released, but only at $\mathrm{pH}$ 9.75 is the amidase activity reflected in the accumulation of FA-Gly-Ieu-OH. At pH 6.8 FA-Gly-Leu-OH is rapidly hydrolyzed by the enzyme and thus no accumulation takes place.

It is obvious from the result in Figures 1 and 2 that a $\mathrm{pH}$ value can be chosen where CPD-Y exhibits amidase activity and peptidyl-aminoacid-amide hydrolase activity but essentially no carboxypeptidase activity. The same results were obtained with longer peptide amide substrates. From the data given in Table $\mathrm{I}$, it is seen that for Ac-(Ala $)_{3}$-Leu- $\mathrm{NH}_{2}$, as well as Ac-(Ala $)_{4}$-His$\mathrm{NH}_{2}, \mathrm{pH} 10$ was necessary to avoid carboxypeptidase activity completely. At $\mathrm{pH}$ values below 10 , an increasing amount of products due to 
Table I

pH-Dependence of amidase, peptidase and peptidyl-amino-acid-amid hydrolase activity of CPD-Y.

\begin{tabular}{|c|c|c|c|c|}
\hline \multirow[b]{2}{*}{ Substrate } & \multirow[b]{2}{*}{ Products formed } & \multicolumn{3}{|c|}{ Product at $\mathrm{pH}$} \\
\hline & & 9.5 & 9.75 & 10.0 \\
\hline $\mathrm{Ac}-(\mathrm{Ala})_{3}-\mathrm{Leu}-\mathrm{NH}_{2}$ & $\begin{array}{l}\mathrm{Ac}-(\mathrm{Ala})_{3}-\mathrm{Leu}-\mathrm{OH} \\
\mathrm{Ac}-(\mathrm{Ala})_{3}-\mathrm{OH} \\
\mathrm{Ac}-(\mathrm{Ala})_{2}-\mathrm{OH} \\
\mathrm{Ac}-\mathrm{Ala}-\mathrm{OH}\end{array}$ & $\begin{array}{c}<1 \% \\
50 \\
30 \\
20\end{array}$ & $\begin{array}{l}15 \\
75 \\
10\end{array}$ & $\begin{array}{l}50 \\
50 \\
<\quad 1 \% \\
<\quad 1 \%\end{array}$ \\
\hline Ac-(Ala) $)_{3}-\mathrm{Ile}-\mathrm{NH}_{2}$ & $\begin{array}{l}\text { Ac-(Ala })_{3}-I l e-O H \\
\text { Ac-(Ala })_{3}-\mathrm{OH} \\
\text { Ac-(Ala })_{2}-\mathrm{OH} \\
\text { Ac-Ala-OH }\end{array}$ & $\begin{array}{r}5 \\
15 \\
80\end{array}$ & $\begin{array}{l}35 \\
65\end{array}$ & $\begin{array}{l}30 \\
70\end{array}$ \\
\hline $\mathrm{Ac}-(\mathrm{Ala})_{4}-\mathrm{His}-\mathrm{NH}_{2}$ & $\begin{array}{l}\mathrm{Ac}-(\mathrm{Ala})_{4}-\mathrm{His}-\mathrm{OH} \\
\mathrm{Ac}-(\mathrm{Ala})_{4}-\mathrm{OH} \\
\mathrm{Ac}-(\mathrm{Ala})_{3}-\mathrm{OH} \\
\mathrm{Ac}-(\mathrm{Ala})_{2}-\mathrm{OH} \\
\mathrm{Ac}-\mathrm{Ala}-\mathrm{OH}\end{array}$ & $\begin{array}{c}<1 \% \\
40 \\
20 \\
40 \\
<1 \%\end{array}$ & $\begin{array}{c}<1 \% \\
50 \\
20 \\
30 \\
<1 \%\end{array}$ & $\begin{array}{c}<1 \% \\
>80 \\
5 \\
15 \\
<1 \%\end{array}$ \\
\hline
\end{tabular}

Substrate was $2 \mathrm{~mm}$ in $0.1 \mathrm{~m}-\mathrm{KCl}, 1 \mathrm{~mm}$-EDTA. CPD-Y was $15 \mu \mathrm{M}$. $200 \mu \mathrm{l}$ aliquots were quenched into $1 \mathrm{ml}$ $\mathrm{CH}_{3} \mathrm{CN}$ and analyzed by HPLC. Entire peaks were collected and subjected to amino acid analysis from which the molar ratios of the products were calculated.

carboxypeptidase activity appears in the reaction mixture

Since the unexpected peptidyl-amino-acidamide hydrolase activity had not previously been characterized, it was important to establish the dependence of this activity of CPD-Y on the structure of the substrate. Single step release of amino acid amide could be demonstrated with all the substrates tested (Table I and II). However, the ratio of this activity to the amidase activity was strongly dependent on the configuration of the side chain of the C-terminal amino acid. The considerable difference between the reaction course of Bz-Ala-Ile- $\mathrm{NH}_{2}$ and Bz-Ala-Leu- $\mathrm{NH}_{2}$ is especially noteworthy.

\subsection{Peptide amides as substrates in peptide synthesis}

Since the objective in the CPD-Y catalyzed peptide synthesis (29) is to extend a peptide chain by addition of one amino acid residue, it was expected, considering the data in Table II, that peptide amides would be of limited use as substrates in this type of peptide synthesis. This is confirmed from the data in Table III, where only the substrates Bz-Ala-Leu- $\mathrm{NH}_{2}$ and Bz-AlaPhe- $\mathrm{NH}_{2}$ resulted in synthesis of peptides in good yields. Using the four other substrates, peptidyl-amino-acid-amide hydrolase activity

\section{Table II}

Dependence of peptidyl-amino-acid-amide hydrolase and amidase activities on substrate structure ${ }^{a}$.

\begin{tabular}{lcc}
\hline & \multicolumn{2}{c}{ Products formed (\%) } \\
\cline { 2 - 3 } Substrates & Bz-Ala-OH & Bz-Ala-X-OH \\
\hline & 79 & $\%$ \\
Bz-Ala-Ala-NH & 21 \\
Bz-Ala-Thr-NH & 95 & 5 \\
Bz-Ala-Val-NH & 92 & 8 \\
Bz-Ala-Ile-NH & 84 & 16 \\
Bz-Ala-Leu-NH & 29 & 71 \\
Bz-Ala-Phe-NH & 35 & 65 \\
\hline
\end{tabular}

a) Conditions: $5 \mathrm{~mm}$ substrate, $10 \% \mathrm{DMF}, 0.1 \mathrm{~m}$ $\mathrm{KCl} 1 \mathrm{~mm}$-EDTA, pH 10.0. CPD-Y $=40 \mu \mathrm{M}$. Room temperature. $\mathrm{X}=$ The $\mathrm{C}$-terminal amino acid residue of the substrates. 
Table III

Peptide amides as substrates in CPD-Y catalyzed transpeptidations using amino acid amides as nucleophilesa).

\begin{tabular}{|c|c|c|c|c|}
\hline \multirow{3}{*}{$\frac{\text { Substrates }}{\text { Bz-Ala-Ala- } \mathrm{NH}_{2}}$} & \multicolumn{4}{|c|}{ Products formed using two different nucleophiles } \\
\hline & Valine amide $(0.25 \mathrm{M})$ & & Phenylalanine amide $(0.25 \mathrm{M})$ & \\
\hline & $\begin{array}{l}\text { Bz-Ala-Ala-Val- } \mathrm{NH}_{2} \\
\text { Bz-Ala-Val-NH } \\
\text { Bz-Ala-OH }\end{array}$ & $\begin{array}{l}18 \% \\
70 \% \\
12 \%\end{array}$ & $\begin{array}{l}\text { Bz-Ala-(Phe })_{n}-\mathrm{NH}_{2}(\mathrm{n}>2) \\
\text { Bz-Ala-Phe-OH } \\
\text { Bz-Ala-OH }\end{array}$ & $\begin{array}{r}95 \% \\
4 \% \\
1 \%\end{array}$ \\
\hline Bz-Ala-Thr- $\mathrm{NH}_{2}$ & $\begin{array}{l}\text { Bz-Ala-Val-NH }{ }_{2} \\
\text { Bz-Ala-OH }\end{array}$ & $\begin{array}{l}90 \% \\
10 \%\end{array}$ & $\begin{array}{l}\text { Bz-Ala-(Phe })_{n-N_{2}}(n>2) \\
\text { Bz-Ala-Phe-OH }\end{array}$ & $\begin{array}{l}83 \% \\
17 \%\end{array}$ \\
\hline Bz-Ala-Val- $\mathrm{NH}_{2}$ & Bz-Ala-Val- $-\mathrm{NH}_{2}$ & $100 \%$ & $\mathrm{Bz}-\mathrm{Ala}-(\mathrm{Phe})_{\mathrm{n}}-\mathrm{NH}_{2}(\mathrm{n}>2)$ & $100 \%$ \\
\hline Bz-Ala-Ile- $\mathrm{NH}_{2}$ & $\begin{array}{l}\text { Bz-Ala-Val-NH } \\
\text { Bz-Ala-OH }\end{array}$ & $\begin{array}{l}81 \% \\
19 \%\end{array}$ & $\begin{array}{l}\text { Bz-Ala-(Phe })_{n}-\mathrm{NH}_{2}(\mathrm{n}>2) \\
\text { Bz-Ala-Phe-OH } \\
\text { Bz-Ala-Ile-OH }\end{array}$ & $\begin{array}{r}77 \% \\
16 \% \\
7 \%\end{array}$ \\
\hline Bz-Ala-Leu- $\mathrm{NH}_{2}$ & $\begin{array}{l}\text { Bz-Ala-Leu-Val- } \mathrm{NH}_{2} \\
\text { Bz-Ala-Val- } \mathrm{NH}_{2}\end{array}$ & $\begin{array}{l}65 \% \\
35 \%\end{array}$ & $\begin{array}{l}\text { Bz-Ala-Leu-Phe- } \mathrm{NH}_{2} \\
\text { Bz-Ala-Leu-Phe-Phe- } \mathrm{NH}_{2} \\
\text { Bz-Ala-Phe-Phe-NH} \\
\text { Bz-Ala-Phe-OH } \\
\text { Bz-Ala-Phe-Phe-OH }\end{array}$ & $\begin{array}{l}16 \% \\
31 \% \\
18 \% \\
17 \% \\
19 \%\end{array}$ \\
\hline Bz-Ala-Phe- $\mathrm{NH}_{2}$ & $\begin{array}{l}\text { Bz-Ala-Phe-Val-NH } \\
\text { Bz-Ala-Val- } \mathrm{NH}_{2} \\
\text { Bz-Ala-OH } \\
\text { Bz-Ala-Phe-OH }\end{array}$ & $\begin{array}{r}44 \% \\
35 \% \\
5 \% \\
16 \%\end{array}$ & $\begin{array}{l}\text { Bz-Ala-Phe-(Phe })_{n}-\mathrm{NH}_{2}(\mathrm{n}>2) \\
\text { Bz-Ala-OH } \\
\text { Bz-Ala-Phe-OH }\end{array}$ & $\begin{array}{l}77 \% \\
10 \% \\
13 \%\end{array}$ \\
\hline
\end{tabular}

a) Conditions: See Table II. The numbers indicate the proportion of each product in the reaction mixture.

Table IV

Peptide amides as substrates in CPD-Y catalyzed transpeptidations using amino acids as nucleophiles").

\begin{tabular}{llllr}
\hline \multirow{2}{*}{ Substrates } & \multicolumn{3}{c}{ Products formed using two different nucleophiles } \\
\cline { 2 - 5 } & Valine (0.5M) & \multicolumn{2}{c}{ Phenylalanine (0.25M) } \\
\hline Bz-Ala-Val-NH 2 & Bz-Ala-Val-OH & $75 \%$ & Bz-Ala-Phe-OH & $18 \%$ \\
& Bz-Ala-OH & $25 \%$ & Bz-Ala-OH & $65 \%$ \\
& & & Bz-Ala-Val-OH & $17 \%$ \\
Bz-Ala-Ile-NH & & & & \\
& Bz-Ala-Ile-Val-OH & $11 \%$ & Bz-Ala-Ile-Phe-OH & $5 \%$ \\
& Bz-Ala-Val-OH & $55 \%$ & Bz-Ala-Phe-OH & $25 \%$ \\
& Bz-Ala-OH & $22 \%$ & Bz-Ala-OH & $42 \%$ \\
& Bz-Ala-Ile-OH & $12 \%$ & Bz-Ala-Ile-OH & $27 \%$ \\
& & & & \\
Bz-Ala-Leu-NH & & $11 \%$ & Bz-Ala-Leu-Phe-OH & $2 \%$ \\
& Bz-Ala-Leu-Val-OH & $14 \%$ & Bz-Ala-Phe-OH & $11 \%$ \\
& Bz-Ala-Val-OH & $9 \%$ & Bz-Ala-OH & $11 \%$ \\
& Bz-Ala-OH & Bz-Ala-Leu-OH & $76 \%$ \\
& Bz-Ala-Leu-OH & $67 \%$ & Bz-OH
\end{tabular}

a) Conditions: See Table II. The numbers indicate the proportions of each product in the reaction mixture. 
predominates, and the last amino acid residue of the substrate is thus lacking in the majority of the product(s). Since, the products which are formed in these reactions are often better substrates than the starting substrates, oligomerization is sometimes observed. This is especially evident when $\mathrm{H}-\mathrm{Phe}-\mathrm{NH}_{2}$ is used as nucleophile. If, on the other hand, the product is a poorer substrate than the starting substrate, good yields can be obtained without oligomerization, e.g., Bz-Ala-Phe- $\mathrm{NH}_{2}+\mathrm{H}-\mathrm{Val}-\mathrm{NH}_{2}$ (Table III).

When amino acids are used as nucleophiles, oligomerization is of course no problem. The yields of the desired products are, however, rather low for the substrates tested (Table IV).

\subsection{Peptides as substrates in peptide synthesis}

Peptides cannot be of any use as substrates in a CPD-Y catalyzed sequential peptide synthesis reaction because the $\mathrm{C}$-terminal amino acid residue is lost, and thus no peptide chain elongation will take place. However, incorporation of a new amino acid residue in place of an existing residue, by transpeptidation, might be of interest in special cases. Since at neutral $\mathrm{pH}$

\section{Table V}

Peptides as substrates in CPD-Y catalyzed transpeptidations $^{a}$.

\begin{tabular}{llr}
\hline Substrate & Product & Yield \\
\hline Z-Ala-Gly-OH & Z-Ala-Leu-NH & $80 \%$ \\
Bz-Phe-Gly-OH & Bz-Phe-Leu-NH & $90 \%$ \\
Z-Ala-Ala-OH & Z-Ala-Leu-NH $_{2}$ & $80 \%$ \\
Z-Phe-Ala-OH & Z-Phe-Leu-NH & $60 \%$ \\
Ac-Ala $-O H$ & Ac-Ala2-Leu-NH & $70 \%$ \\
Ac-Ala $4-O H$ & Ac-Ala3-Leu-NH & $70 \%$ \\
Z-Phe-Ser-OH & Z-Phe-Leu-NH & $70 \%$ \\
Z-Ala-Val-OH & Z-Ala-Leu-NH & $10 \%$ \\
Z-Gly-Leu-OH & Z-Gly-Leu-NH & $0 \%$ \\
Z-Phe-Leu-OH & Z-Phe-Leu-NH & $0 \%$ \\
Bz-Gly-Phe-OH & Bz-Gly-Leu-NH & $10 \%$ \\
Z-Ala-Phe-OH & Z-Ala-Leu-NH & $0 \%$ \\
Z-Phe-Phe-OH & Z-Phe-Leu-NH & $10 \%$ \\
\hline
\end{tabular}

a) Conditions: $10 \mathrm{~mm}$ substrate, $0.1 \mathrm{M}-\mathrm{KCl}, 1 \mathrm{~mm}-$ EDTA, 0.25 m-leucine amide, $\mathrm{pH} 7.5, \mathrm{CPD}-\mathrm{y}=$ $4-25 \mu \mathrm{M}$. Aliquots taken out after $60 \mathrm{~min}$. $0 \%$ yield indicates that no transpeptidation has taken place, i.e. all substrate hydrolyzed.
CPD-Y hydrolyses peptides much faster than peptide amides, it was expected that complications from oligomerization could be avoided by using amino acid amides as nucleophiles. The yields of such transpeptidation reactions using different peptide substrates and H-Leu- $\mathrm{NH}_{2}$ as the nucleophile are listed in Table $\mathrm{V}$. The results indicate a strong dependence of the yields on the size of the C-terminal residue in the substrate. Only in cases where the leaving group is glycine, alanine or serine is the reaction successful. Furthermore, at least for the substrates tested there was no dependence on the penultimate residue.

\section{DISCUSSION}

In order for CPD-Y to successfully catalyze the formation of peptide bonds, two conditions must be met. Firstly, an acyl-enzyme intermediate must be formed (5), and secondly, the amino acid or amino acid derivative used as nucleophile must bind to the enzyme at a specific location for the nucleophilic attack on the acyl-enzyme intermediate. A third condition must also be fulfilled if the result of this process is to be observed: The synthesized product, if itself a substrate under the conditions used, should be hydrolyzed at a much lower rate than the initial substrate.

Considering the high level of esterase activity at $\mathrm{pH}>9$, where amidase activity is relatively low and carboxypeptidase activity negligible, the most obvious approach employing CPD-Y in peptide synthesis, was to use peptide esters as substrates and amino acids or amino acid amides as nucleophiles (29). However, since the first condition (formation of an acyl-enzyme intermediate) is met for all substrates of CPD-Y, substrates other than alkyl esters might be of use in peptide synthesis. The present paper deals with substrates where the acyl-enzyme is formed by scission of $\mathrm{C}-\mathrm{N}$ bonds. Since, as is the purpose of peptide synthesis, new $\mathrm{C}-\mathrm{N}$ bonds are formed subsequently, the whole process corresponds formally to an acyl-type transpeptidation $(13,28)$. If such reactions are to be utilized for peptide elongation, the leaving group has to be ammonia. If amino acids or amino acid amides function as leaving groups, an exchange of the Cterminal residue of the peptide occurs. 
The presence of peptidyl-amino-acid-amide hydrolase activity in addition to amidase activity was unexpected (Table I and II), since such an activity has been assumed to be specific for endopeptidases. To apply this term to CPD-Y would however be erroneous since release of fragments longer than one amino acid residue has not been documented. Instead it must be concluded that the release of amino acid amides from peptide amides is not confined to endopeptidases. Apparent endoproteolytic activity has also been observed for an aminopeptidase, and the term endoexopeptidase was suggested (14). Only one other hydrolytic enzyme is known to release a $\mathrm{C}$-terminal amino acid amide from a peptide amide $(7,20,27)$. Its activity is however restricted to the cleavage of glycine amide from [8-arginine] vasopressin and oxytocin. It is remarkable though, that this enzyme shares common characteristics of many serine car-
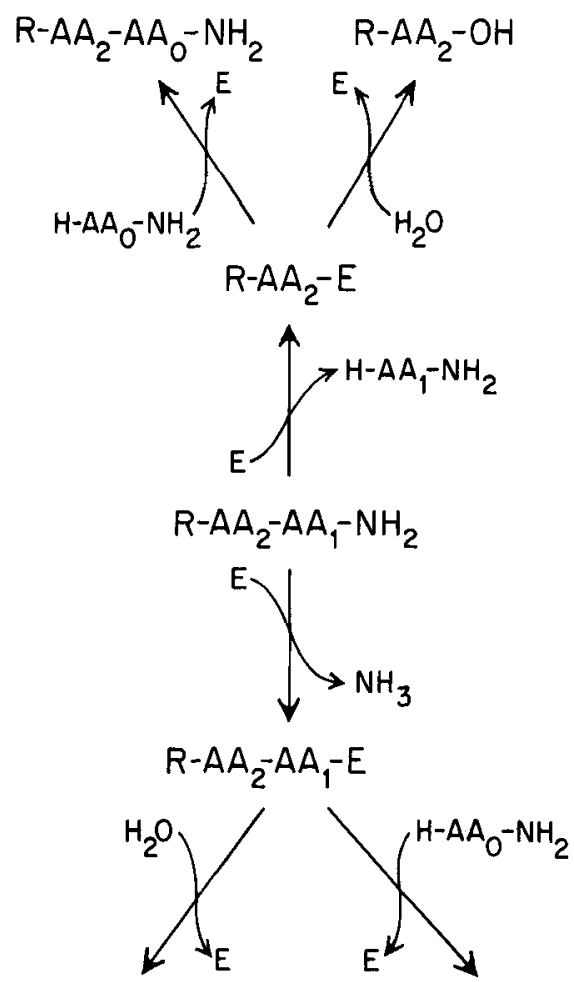

$\mathrm{R}-\mathrm{AA}_{2}-\mathrm{AA_{1 }}-\mathrm{OH}$

$\mathrm{R}-\mathrm{A} \mathrm{A}_{2}-\mathrm{AA_{1 }}-\mathrm{AA_{0 }}-\mathrm{NH}_{2}$

Scheme 1. Product distribution using peptide amides as substrates and amino acid amides as nucleophiles.

$\mathrm{AA}=$ amino acid residue; $\mathrm{R}=$ peptidyl; $\mathrm{E}=$ CPD-Y. boxypeptidases (cf. ref. 24 for a summary) i.e., it is inhibited by reagents specific for serine proteases as well as by those reacting with sulfhydryl groups (27).

For CPD-Y, the amount of peptidyl-aminoacid-amide hydrolase activity compared to the competing amidase activity seems to be strongly dependent on the structure of the terminal amino acid (Table II), e.g., 79\% peptidyl-amino-acidamide hydrolase activity using Bz-Ala-Ala- $\mathrm{NH}_{2}$ as substrate while only $29 \%$ using Bz-Ala-Leu$\mathrm{NH}_{2}$. Although increasing the hydrophobicity of the side chain of the terminal amino acid seems to favor amidase activity, the presence of a branched $\beta$-carbon atom as in Bz-Ala-Ile- $\mathrm{NH}_{2}$ and $\mathrm{Bz}-\mathrm{Ala}-\mathrm{Val}-\mathrm{NH}_{2}$ results in higher peptidylamino-acid-amide hydrolase activity (Table II).

Based on the results in Table II it was not expected that amides would be of general use as substrates in peptide synthesis. The data in Tables III and IV confirm that the presence of the two competing activities towards the same substrate results in two different reaction paths (cf. Scheme 1). Thus, using valine amide as nucleophile, the CPD-Y catalyzed reaction with Bz-Ala-Leu- $\mathrm{NH}_{2}$ leads to the formation of two products: Bz-Ala-Val- $\mathrm{NH}_{2}(35 \%)$ and Bz-AlaLeu-Val- $\mathrm{NH}_{2}(65 \%)$. As can be seen from this example, the distribution of the products is in good accordance with expectations based on hydrolysis of this substrate in the absence of nucleophile (Table II).

Lack of specificity is, however, not the only problem when using peptide amides as substrates. Though high coupling yields are obtained with amino acid amides as nucleophiles, problems arise from the fact that the resultant products, being peptide amides, are themselves substrates of the enzyme. If then ammonia serves as leaving group of the new substrate, oligomerization is observed. In the reaction of Bz-Ala-Ala- $\mathrm{NH}_{2}$ with $\mathrm{H}$-Phe- $\mathrm{NH}_{2}$ (Table III), the dominant product formed is Bz-Ala-Phe$\mathrm{NH}_{2}$, since the peptidyl-amino-acid-amide hydrolase activity in this case is far greater than amidase activity. However, the product Bz-AlaPhe- $\mathrm{NH}_{2}$, is a better substrate than the starting material. Thus, as the product accumulates, an increasing proportion of the acyl-enzyme intermediates will be formed from the product with the consequent formation of Bz-Ala-Phe-Phe- 
$\mathrm{NH}_{2}$ (since amidase activity towards Bz-AlaPhe- $\mathrm{NH}_{2}$ dominates over peptidyl-amino-acidamide hydrolase activity). The sequence of events then repeats itself, the result being oligomerization. In cases where the product is a poorer substrate than the starting material, a larger concentration of product can be accumulated before it is attacked by the enzyme to any significant degree. Needless to say, if the enzyme only exhibits peptidyl-amino-acid-amide hydrolase activity towards the product formed, oligomerization will not be a disturbing side reaction. With Bz-Ala-Leu- $\mathrm{NH}_{2}$ and $\mathrm{H}-\mathrm{Val}$ $\mathrm{NH}_{2}$, for example, Bz-Ala-Leu-Val- $\mathrm{NH}_{2}$ is formed in a $65 \%$ yield without any oligomerization. This is most likely due to the fact that a Cterminal valine amide in the substrate results in predominant peptidyl-amino-acid-amide hydrolase activity (Table II), and thus no further elongation can take place.

Ideally, as mentioned earlier, the product of a coupling step should not be a substrate. The formation of peptides from peptide amides and amino acids at $\mathrm{pH} 10$ demonstrates such a case. It is therefore unfortunate that peptide elongation does not seem feasible using this procedure due to low coupling yields, e.g., from Bz-AlaLeu- $\mathrm{NH}_{2}$ and valine only $11 \%$ Bz-Ala-Leu-Val$\mathrm{OH}$ was formed (Table IV). Thus, peptide amides are not of general value as substrates in CPD-Y catalyzed peptide elongation. It could be demonstrated, however, that with amino acid amides as nucleophiles the amidase activity of CPD-Y can be utilized for this purpose in cases where the product is a poorer amidase substrate than the initial substrate. Under these circumstances high coupling yields are obtained because little or no oligomerization occurs. The importance of being able to use peptide amides as substrates in CPD-Y catalyzed peptide synthesis lies in the fact that presently peptide amides can be synthesized in much better yields than the corresponding peptides (29). The direct use of these peptide amides in the following elongation step would be very convenient.

The advantages of using CPD-Y in enzymatic peptide synthesis compared to any other enzyme currently used for this purpose $(9,10,11,17$, $19,21,22,23)$ lies in its unique specificity $(8)$. In contrast to the endopeptidases, CPD-Y does not split any internal peptide bonds. Amino acids or amino acid derivatives can be added sequentially under conditions where the C-terminal amino acid residues will not be cleaved off the growing peptide chain (29). The data presented in this paper further explore the specificity of CPD-Y and outline other possibilities for its use in this new field of peptide synthesis. While the unexpected existence of the peptidyl-amino-acidamide hydrolase activity presents a hurdle for sequential synthesis, it may be of value for $\mathrm{C}$ terminal semisynthetic manipulations.

On the basis of the data so far accumulated, caution must be exerted in predicting the amount of peptidyl-amino-acid-amide hydrolase activity of CPD-Y toward untested substrates. In order for the enzyme to exhibit amidase activity, the Cterminal amino acid residue of the peptide amide must be bound in the $S_{1}$ site (26). If the $C$ terminal residue is bound in the $S_{\mid}^{\prime}$ site, the enzyme exhibits peptidyl-amino-acid-amide hydrolase activity. The reaction course of a given peptide amide is most likely a result of its relative affinity for these two different modes of binding. Although a strong dependence on the nature of the terminal residue has been documented, it cannot be concluded that this residue is solely responsible for the binding mode of the peptide amide. For other proteolytic enzymes strong influence of up to 5-7 subsites on the binding of peptides has been described $(1,2,26,30)$ and CPD-Y need not be an exception. It is possible that not only the reaction course but also the individual coupling yields will be affected by such factors. In fact, an unexpectedly high coupling yield $(70 \%)$ with H-Tyr-Gly-Gly-Phe$\mathrm{NH}_{2}$ and methionine to form H-Tyr-Gly-GlyPhe-Met was obtained (to be published). It is therefore evident that in each elongation step many different approaches should be tested until more general knowledge about this method of peptide synthesis has been accumulated and thus predictions can be made.

Peptide synthesis in liquid- or solid phase, with or without enzymes, deals with the sequential coupling of an amino acid residue to a peptide chain. In addition to being able to catalyze such reactions, CPD-Y is also able to catalyze the exchange of the $\mathrm{C}$-terminal residue of peptides as well as peptide amides. From the results in Table $\mathrm{V}$ it can be seen that when peptides are used as substrates the leaving group 
has to be one of the smallest amino acids, i.e., glycine, alanine or serine, if a successful incorporation of the nucleophile is to be obtained. When peptide amides are used as substrates, no such structural dependence of the leaving group could be documented. However, the scope of amino acid amide exchange is limited by the fact that only those peptides which end on a small amino acid amide or some larger ones with a branched $\beta$-carbon, are substrates resulting in predominant peptidyl-amino-acid-amide hydrolase activity (see above). Nevertheless, the ability of CPD.Y to form an acyl-enzyme intermediate via its peptidyl-amino-acid-amide hydrolase activity should enable $\mathrm{C}$-terminal modifications of many peptides of biological significance.

It is thus apparent that the wide range of activities of CPD-Y can be of considerable use in the field of peptide chemistry. There is however no reason to believe that CPD-Y is the only serine carboxypeptidase able to catalyze the formation of peptide bonds. Similar enzymes from other sources have been characterized, although not to the same extent $(15,24)$. Some of these enzymes may have specificities which might supplement those of CPD-Y and thus widen and extend the use of this class of enzymes in enzymatic peptide synthesis.

\section{ACKNOWLEDGEMENTS}

The authors are indepted to Professor MARTIN OTTESEN for many helpful suggestions at all stages of the work. The excellent technical assistance of Mss. Bodil Corneliussen, Irene Simonsen and Edith Fløistrup is gratefully acknowledged. F. WIDMER gratefully acknowledges the Swiss National Science Foundation for a Post-Doctoral Fellowship.

\section{REFERENCES}

1. Abramowitz, N., I. Schechter \& A. Berger: On the size of the active site in proteases. II. Carboxypeptidase A. Biochem. Biophys. Res. Commun. 29, 862-867 (1967)

2. Atlas, D. \& A. Berger: On the specificity of elastase. Hydrolysis of peptide p-nitrobenzylesters. Biochemistry 11, 4719-4723 (1972)

3. Auld, D. S. \& B. L. ValleE: Kinetics of carboxypeptidase A. II. Inhibitors of the hydro- lysis of oligopeptides. Biochemistry 9, 602-609 (1970)

4. BlaU, K. \& S. G. Waley: Chymotrypsin catalyzed transpeptidations. Biochem. J. 57, 538-54l (1954)

5. Fastrez, J. \& A. R. Ferscht: Demonstration of the acyl-enzyme mechanism for the hydrolysis of peptides and anilides by chymotrypsin. Biochemistry 12, 2025-2034 (1973)

6. Feder, J. \& M. Stuck: Studies on the Bacillus subtilis Neutral-Protease- and Bacillus thermoproteolyticus Thermolysin-catalyzed hydrolysis. Biochemistry 9, 2784-2791 (1970)

7. Fruhaufova, L., E. Suska-Brzezinska, T. BARTH \& I. RYCHLIK: Rat liver enzyme inactivating oxytocin and its deamino-carba analogues. Coll. Czech.Chem.Commun. 38, 2793-2798 (1973)

8. Hayashi, R., Y. Bai \& T. Hata: Kinetic studies of carboxypeptidase Y. I. Kinetic parameters for hydrolysis of synthetic substrates. J. Biochem. (Tokyo) 77, 69-79 (1975)

9. Isowa, Y., M. OHmori, T. Ichikawa, H. Kurita, M. Sato \& K. Mori: The synthesis of peptides by means of proteolytic enzymes. Bull. Chem. Soc. Japan 50, 2762-2765 (1977)

10. Isowa, Y., M. Ohmori, M. Sato \& K. Mori: The enzymatic synthesis of protected valine-5 angiotensin II amide-1. Bull.Chem.Soc. Japan 50, 2766-2772 (1977)

11. Isowa, Y., T. Ichikawa \& M. Ohmori: Peptide synthesis with proteinases. Fragment condensation of ZLeuGInGlyOH or ZGInGlyOH with $\mathrm{HLeuValNH}_{2}$ using metalloproteinases. Bull.Chem.Soc. Japan 51, 271-276 (1978)

12. Johansen, J. T., K. Breddam \& M. OtTesen: Isolation of carboxypeptidase $\mathrm{Y}$ by affinity chromatography. Carlsberg Res. Commun. 41, 1-14 (1976)

13. Katchalski, E. \& M. Sela: Enzymatic synthesis of poly- $\alpha$-amino acids. In: Advances in protein chemistry. C. B. Anfinsen, L. L. Anson, K. Bailey and J. T. Edsall, eds., Academic Press, New York, 13, 369-492 (1958)

14. Kirschke, H.: Cathepsin H. An endoaminopeptidase. Acta Biol.Med. Germ. 36, 1547-1548 (1977)

15. Kubota, Y., S. Shojl, T. Funakoshi, H. Ueki: Carboxypeptidase $\mathrm{C}_{\mathrm{N}}$ I. Purification and characterization of the enzyme from the exocarp of Citrus natsudaidai Hayata. J.Biochem. (Tokyo) 74, 757-770 (1973)

16. LeE, H.-M. \& J. F. RioRDAN: Does carboxypeptidase $\mathrm{Y}$ have intrinsic endopeptidase activity. Biochem.Biophys. Res.Commun. 85, 1135-1142 (1978) 
17. Luisi, P. L., R. Saltman, D. Vlach \& R. Guarnaccia: Co-oligopeptides of glycerine and aromatic amino acids with variable distance between the aromatic residues. VIII. Enzymatic synthesis of $\mathrm{N}$-protected dipeptide esters. J.Mol.Catalysis 2, 133-138 (1977)

18. Martin, B. M., R. W. A. Oliver, J. T. Johansen \& T. Viswanatha: The carboxypeptidase Y catalyzed hydrolysis of indoleacryloylimidazole. Carlsberg Res. Commun. 45, 69-78 (1980)

19. Morihara, K. \& T. Oka: $\alpha$-chymotrypsin as the catalyst for peptide synthesis. Biochem. J. 163 , 531-542 (1977)

20. Nardaccl, N. J., S. Mukhopadhyay \& B. J. CAmpbell: Partial purification and characterization of the antidiuretic hormone-inactivating enzyme from renal plasma membranes. Biochem. Biophys. Acta 377, 146-157 (1975)

21. OKa, T. \& K. Morihara: Protease as a catalyst for peptide synthesis: Synthesis in the absence of product precipitation. Symp. on Peptide Chemistry in Japan, Osaka 79-84 (1977)

22. OKa, T. \& K. Morihara: Trypsin as a catalyst for peptide synthesis. J. Biochem. 82, 10551062 (1977)

23. OKa, T. \& K. Morihara: Peptide bond synthesis catalyzed by $\alpha$-chymotrypsin. J. Biochem. 84 , 1277-1283 (1978)

24. RAY, L. E.: Large scale isolation and partial characterization of some carboxypeptidases from malted barley. Carlsberg Res. Commun. 41, 169-182 (1976)

25. Rivier, J., J. Spiess, M. Perrin \& W. Vale: Application of HPLC in the isolation of unprotected peptides. In: Biological Biomedical Applications of Liquid Chromatography II. G. L. Hawk, ed., Marcel Dekker Inc., New York, 223-24l (1979)

26. Schechter, I. \& B. Berger: On the size of the active site of proteases. I. Papain, Biochem. Biophys. Res. Commun. 27, 157-162 (1967)

27. Simmons, W. H. \& R. Walter: Carboxyamidopeptidase: Purification and characterization of a neurohypophyseal hormone inactivating peptidase from toad skin. Biochemistry 19, 39-48 (1980)

28. WANG, T. T. \& T. HofmanN: Acyl and amino intermediates in reactions catalyzed by pig pepsin. Analysis of transpeptidation products. Biochem. J. 153, 691-699 (1976)

29. Widmer, F. \& J. T. Johansen: Enzymatic peptide synthesis. Carboxypeptidase $Y$ catalyzed formation of peptide bonds. Carlsberg Res. Commun. 44, 37-46 (1979)

30. Үамамото, T. \& N. IzumiYa: Action of trypsin on synthetic substrates. III. Hydrolysis of homologous peptides ranging from diglycyl-Llysyl-glycin to diglycyl-L-lysyl-tetraglycine. Arch. Biochem. Biophys. 120, 497-502 (1967) 